\title{
Enhancement of Host Resistance to Bacterial Infections in Normal and Immunosuppressed Mice with Actinobacillus suis
}

\author{
Takashi WATANABE \\ Department of Clinical Nutrition, Faculty of Health Science, Suzuka University of \\ Medical Science and Technology \\ (Received: February 2, 1996) \\ (Accepted: March 12, 1996) \\ Key words: Actinobacillus suis, immunostimulant, opportunistic infection
}

\begin{abstract}
A single intraperitoneal (ip) inoculation of heat-killed Actinobacillus suis ATCC 15557 (AS 15557) into normal and immunosuppressed (dexamethasone-treated) mice led to remarkable nonspecific resistance to ip challenge with lethal doses of opportunistic pathogens such as Pseudomonas aeruginosa, methicillin-resistant Staphylococcus aureus and Candida albicans. The duration of this enhanced protective action and the minimal effective dose, in normal mice, induced by AS 15557 were superior to those induced by other bacterial immunostimulants such as heat-killed Lavtobacillus casei YIT 9018 (LC 9018) and penicillin-treated Streptococcus pyogenes, Su (OK-432). In immunosuppressed mice, the reduced in vivo killing activity of peritoneal exudate cells (PECs) against $P$. aeruginosa infection was markedly augmented by ip injection of AS 15557. The degree of PEC augmentation induced by AS 15557 was higher than that induced by LC 9018 or by OK-432. The toxicity and histopathological changes associated with AS 15557 were very low, as compared with those by produced by LC 9018 and OK-432. The results suggest that AS 15557, which showed a strong resistance-enhancing capacity against opportunistic bacterial infections, may be a useful bacterial immunostimulant.
\end{abstract}

\section{Introduction}

Bacterial immunostimulants such as Mycobacterium bovis (BCG), Propionibacterium acnes (Corynebacterium parvum) and an attenuated Streptococcus pyogenes are well known to have strong antitumor and antimicrobial actions in experimental animals and patients ${ }^{1 \sim 9)}$. However, it is essential to pay careful attention to side reactions in clinical applications for cancer therapy and/or infectious diseases since these bacteria are naturally pathogenic. As an example, a side reaction such as penicillin-shock due to the $S$. pyogenes cell preparation (OK-432) can occur easily because the attenuation of OK-432 is achieved by treatment with a high dose of penicillin $G^{10)}$. The author and colleagues $^{11 \sim 13)}$ and Mutai et al. ${ }^{14,15)}$ have reported that a heat-killed Lactobacillus casei cell preparation (LC 9018) has strong antimicrobial and antitumor activities in experimental animals. However, L. casei cells having long and polymorphous rod-shapes may cause a secondary side reaction such as enlargement and necrosis of host organs (for instance: the spleen and liver) via bacterial clumping ${ }^{16}$.

Actinobacillus suis, one member of the genus Actinobacillus (A. ligniersii, A. suis, A. equuli, A.

Correspondence to : Takashi WATANABE, pH.D.

Department of Clinical Nutrition, Faculty of Health Science, Suzuka University of Medical Science and Technology, 1001-1 Kishioka, Suzuka 510-02, Mie, Japan 
capsulatus and $A$. actinomycetemcomitans), is a gram-negative capnophilic coccobacillus belonging to the Pasteurellaceae family ${ }^{17}$. A. suis is found as a commensal agent in alimentary, respiratory and genital tracts of several normal animals such as swine, cattle and horses ${ }^{17 \sim 20}$.

There have been no reports, to date, indicating that the genus Actinobacillus cells show immunopotentiating actions against microbial infections. The objective of the present study was to determine whether or not a heat-killed $A$. suis cell preparation shows resistance-enhancing effects on bacterial infections in normal and immunosuppressed animals.

\section{Materials and Methods}

Animals

Five-week-old female ddY mice (weighing 24 to $25 \mathrm{~g}$ ) were purchased from the Shizuoka Agricultural Cooperative for Experimental Animals, Shizuoka, Japan. Immunosuppressed mice were created by intraperitoneal (ip) administration of $0.2 \mathrm{ml}$ of dexamethasone (decadron ${ }^{\circledR}$, Nippon-Merk Co., Tokyo) in $1 \mathrm{mM}$ sodium phosphate buffer ( $\mathrm{pH} 7.2)$ once daily for 3 days $(1 \mathrm{mg} / \mathrm{ml}$; total inoculum: $0.6 \mathrm{mg} / \mathrm{mouse})$.

Bacterial immunostimulants

Cells of A. suis ATCC 15557 (AS 15557) and A. actinomycetemcomitans ATCC 29522 (AA 29522) grown in brain-heart infusion broth (Eiken Chemicals Co., Tokyo) were washed 3 times with saline by centrifugation, suspended in saline, treated in a water-bath at $80^{\circ} \mathrm{C}$ for $30 \mathrm{~min}$, lyophilized and stored at $4^{\circ} \mathrm{C}$ until use. LC 9018 (a lyophilized preparation of heart-killized $L$. casei cells YIT 9018) and OK-432 (penicillin G-treated S. pyogenes $\mathrm{Su}$ ) were donated by Yakult Central Institute for Microbiological Research (Tokyo) and Chugai Pharmaceutical Co. (Tokyo), respectively.

\section{Challenge pathogens}

Wild types of $P$. aeruginosa, methicillin-resistant S. aureus (MRSA) and C. albicans were isolated from patients in Mie University Hospital, Mie, Japan. These pathogens grown in brain-heart infusion broth at $37^{\circ} \mathrm{C}$ for $18 \mathrm{hr}$ were washed 3 times with saline and suspended in saline. The colony-forming units (CFUs) of $P$. aeruginosa, MRSA and $C$. albicans were estimated on nalidixic acid-cetrimide (NAC) agar plates, No. 110 agar plates and Sabourud-Glucose agar plates, respectively.

Evaluation of protective actions of immunostimulants in normal mice

Normal mice, in groups of 10 each, were injected ip with either $0.2 \mathrm{ml}(0.5 \mathrm{mg} / \mathrm{ml} ; 0.1 \mathrm{mg} / \mathrm{mouse}$; $4 \mathrm{mg} / \mathrm{kg})$ or $0.2 \mathrm{ml}(2.5 \mathrm{mg} / \mathrm{ml} ; 0.5 \mathrm{mg} / \mathrm{mouse} ; 20 \mathrm{mg} / \mathrm{kg})$ of one of four kinds of immunostimulants 3 days before ip challenge with $0.2 \mathrm{ml}$ of $P$. aeruginosa $\left(1.8 \times 10^{7} \mathrm{CFUs} / \mathrm{mouse}\right), \mathrm{MRSA}\left(4.4 \times 10^{7}\right.$ CFUs/mouse $)$ or $C$. albicans $\left(1.3 \times 10^{8} \mathrm{CFUs} / \mathrm{mouse}\right)$. The survival rates were recorded on the 10 th day after infection. As controls, mice $(n=10)$ were injected ip with $0.2 \mathrm{ml}$ saline instead of each immunostimulant. For statistical comparison of final survival rates between experimental and control groups, $P$ values were calculated by the chi-square Student's $t$-test. A value of $P<0.05$ was considered to be statistically significant.

Duration of protective actions of immunostimulants against $P$. aeruginosa infection in normal mice

Mice $(n=10)$ were challenged ip with $1.8 \times 10^{7}$ CFUs of $P$. aeruginosa $3,7,10,14$ or 21 days after ip inoculation with $0.5 \mathrm{mg}$ of AS 15557, AA 29522 or LC 9018. The survivors were recorded on day 10 after the challenge.

Protective actions against $P$. aeruginosa infection in normal mice based on administration routes of immunostimulants.

Mice $(\mathrm{n}=10)$ were challenged ip, intravenously (iv) or subcutaneously (sc) with $P$. aeruginosa $\left(1.6-5.2 \times 10^{7} \mathrm{CFUs}\right) 3$ days after ip, iv or sc injection of either AS $15557(0.5 \mathrm{mg})$ or LC $9018(0.5$ $\mathrm{mg})$. The survivors were recorded on day 10 after the challenge. 
Minimal effective immunostimulant dose against $P$. aeruginosa infection in normal mice

Three days before the ip challenge with $P$. aeruginosa $\left(1.8 \times 10^{7} \mathrm{CFUs}\right)$, mice $(\mathrm{n}=10)$ were inoculated ip with various doses $(0.01,0.05,0.1,0.2,0.5$ and $1.0 \mathrm{mg})$ of the immunostimulants tested. The survivors were recorded on the 10th day after the challenge. The minimal effective dose of each immunostimulant was determined by the chi-square Student's $t$-test.

Comparison of protective actions of immunostimulants against $P$. aeruginosa infection in immunosuppressed mice

One day after the last ip treatment with dexamethasone (DM), DM-treated mice $(n=10)$ were injected ip with or without two doses $(0.1$ and $0.5 \mathrm{mg})$ of As 1557, AA 29522, LC 9018 or OK-432. Three days after the injection of each immunostimulant, mice were challenged ip with $P$. aeruginosa $\left(6.2 \times 10^{6} \mathrm{CFUs}\right)$, and the survivors were recorded on day 10 after the challenge.

Assay for in vivo killing activity of PECs from immunosuppressed mice against $P$. aeruginosa infection

This assay system has been described previously ${ }^{13}$. In brief, mice immunosuppressed by DM treatment $(\mathrm{n}=3)$ were challenged ip with $P$. aeruginosa $\left(1.0 \times 10^{5} \mathrm{CFUs}\right) 3$ days after the ip inoculation with $0.1 \mathrm{mg}$ of AS 15557, LC 9018 or OK-432. Three hours later, $2.5 \mathrm{ml}$ of Hanks balanced salt solution (HBSS) containing 4 units heparin/ml was inoculated into the peritoneal cavities of DMtreated mice, and peritoneal fluid was then harvested after gently massaging the abdomen. This procedure was repeated once. As controls (at zero time), the same number of $P$. aeruginosa was inoculated into the peritoneal cavity of normal (DM-untreated) control mice. The peritoneal fluids were harvested immediately and centrifuged at $170 \times \mathrm{g}$ for $10 \mathrm{~min}$. The pooled cell pellets were disrupted with $5 \mathrm{ml}$ of $0.85 \% \mathrm{NH}_{4} \mathrm{Cl}$ solution at room temperature for $20 \mathrm{~min}$ to release the phagocytosed bacteria from PECs. Each sample was serially diluted 10-fold with HBSS, and the number of CFUs was determined by plating on NAC agar plates. The PECs were counted with a hemocytometer under a microscope, and the cell populations of PECs was calculated by measns of the following formula: Killing activity (\%)=Total CFUs (at zero time after $3 \mathrm{hr}$ )/Total CFUs at zero time $\times 100$. In this formula, total CFUs indicates CFUs in the supernatant fluid plus PEC CFUs. The lethal dose $(\mathrm{LD})_{50}$ values of immunostimulants

Normal mice in groups of 5 were each given ip, iv or sc injections, or an oral dose, of either serially 2-fold diluted AS 15557, LC 9018 or OK-432. Mortality was recorded on day 50 after the inoculation. The $\mathrm{LD}_{50}$ value was determined by the method of Reed and Muench ${ }^{21)}$.

Histopathological observations

Mice $(n=3)$ were injected ip with $0.5 \mathrm{mg}(20 \mathrm{mg} / \mathrm{kg})$ of AS 15557 , LC 9018 or OK-432. The liver and spleen were removed on the 10th day after inoculation and fixed in $10 \%$ formalin. As controls, mice $(n=3)$ were injected ip with saline $(0.2 \mathrm{ml})$. Tissue sections of these organs were made from all fixed preparations and stained with hematoxylin and eosin solution.

\section{Results}

Comparison of protective actions of immunostimulants against infections with bacterial pathogens in normal mice

As shown in Table 1, normal mice mainfested significantly enhanced resistance to $P$. aeruginosa, MRSA and C. albicans infections with all four kinds of immunostimulants (AS 15557, AA 29522, LC 9018 and OK-432) tested. Among them, the protective actions of the genus Actinobacillus (AS and AA) were comparatively stronger than those of LC 9018 and OK-432. In particular, AS 15557 exhibited the highest host resistance-enhancing capacity.

Duration of protective action of immunostimulants against $P$. aeruginosa infection in normal mice 
Table 1 Comparison of protective actions of bacterial immunostimulants against infection with opportunistic pathogens in normal mice

\begin{tabular}{lccccc}
\hline \multirow{2}{*}{ Groups } & \multicolumn{2}{c}{ Doses } & & \multicolumn{3}{c}{ Survivors (\%) } \\
\cline { 5 - 6 } \cline { 5 - 6 } & & & \multicolumn{3}{c}{ Pathogens } \\
\cline { 5 - 7 } & mg/kg & $\begin{array}{c}\text { P. aeru- } \\
\text { ginosa }\end{array}$ & MRSA & $\begin{array}{c}\text { C. albi- } \\
\text { cans }\end{array}$ \\
\hline AS 15557-a) & $4(0.1)$ & $90^{* *}$ & $60^{*}$ & $80^{* *}$ \\
administered & $20(0.5)$ & & $100^{* *}$ & $90^{* *}$ & $90^{* *}$ \\
AA 29522-b) & $4(0.1)$ & & $60^{*}$ & $60^{*}$ & $70^{*}$ \\
administered & $20(0.5)$ & & $80^{* *}$ & $80^{* *}$ & $90^{* *}$ \\
LC 9018-c) & $4(0.1)$ & & 40 & 30 & $50^{*}$ \\
administred & $20(0.5)$ & & $70^{*}$ & $70^{*}$ & $80^{* *}$ \\
OK-432-d) & $4(0.1)$ & & 20 & 20 & 40 \\
administered & $20(0.5)$ & & $70^{*}$ & 40 & $60^{*}$ \\
Control(none) & - & & 0 & 0 & 0 \\
\hline
\end{tabular}

Mice $(n=10)$ were injected ip with one of the test immunostimulants 3 days before ip challenge with $P$. aer uginosa $\left(1.8 \times 10^{7} \mathrm{CFUs}\right)$, MRSA $\left(4.4 \times 10^{7} \mathrm{CFUs}\right)$ or $C$. albicans $\left(1.3 \times 10^{7} \mathrm{CFUs}\right)$. Survival rates were recorded on the 10th day after the challenge. a) AS 15557 (A. suis ATCC 15557), b) AA 29522 (A. actinomycetemcomitans ATCC 29522), c) LC 9018 (L. casei YIT 9018), d) OK-432 (penicillin G-treated $S$. pyogenes, $\mathrm{Su}$ ).

${ }^{*} p<0.05,{ }^{* *} p<0.01$.
Table 2 Protective actions against $P$. aeruginosa infection in normal mice based on immunostimulant administration routes

\begin{tabular}{lccc}
\hline \multirow{2}{*}{ Groups } & \multicolumn{3}{c}{ Survivors (\%) } \\
\cline { 2 - 4 } & ip & iv & sc \\
\hline AS 15557- & & & \\
administered & & 20 & 0 \\
ip & $90^{* *}$ & $50^{*}$ & - \\
iv & 30 & 0 & $60^{*}$ \\
sc & 0 & & \\
\hline LC 9018- & & & 0 \\
administered & & 20 & - \\
ip & $70^{*}$ & 40 & 40 \\
iv & 20 & 0 & \\
sc & 0 & & \\
\hline
\end{tabular}

Mice $(n=10)$ preinoculated ip, iv or sc with AS 15557 $(0.5 \mathrm{mg})$ or LC $9018(0.5 \mathrm{mg})$ were challenged $\left(1.8 \times 10^{7}\right.$ CFUs), iv $\left(1.6 \times 10^{7} \mathrm{CFUs}\right)$ or sc $\left(5.2 \times 10^{7} \mathrm{CFUs}\right)$ with $P$. aeruginosa 3 days after inoculation of one of the two immunostimulants. Survival rates were recorded on day 10 after the challenge. $p<0.05, p<0.01$.

Fig. 1 Durations of protective actions of immunostimulants against $P$. aeruginosa infection in normal mice

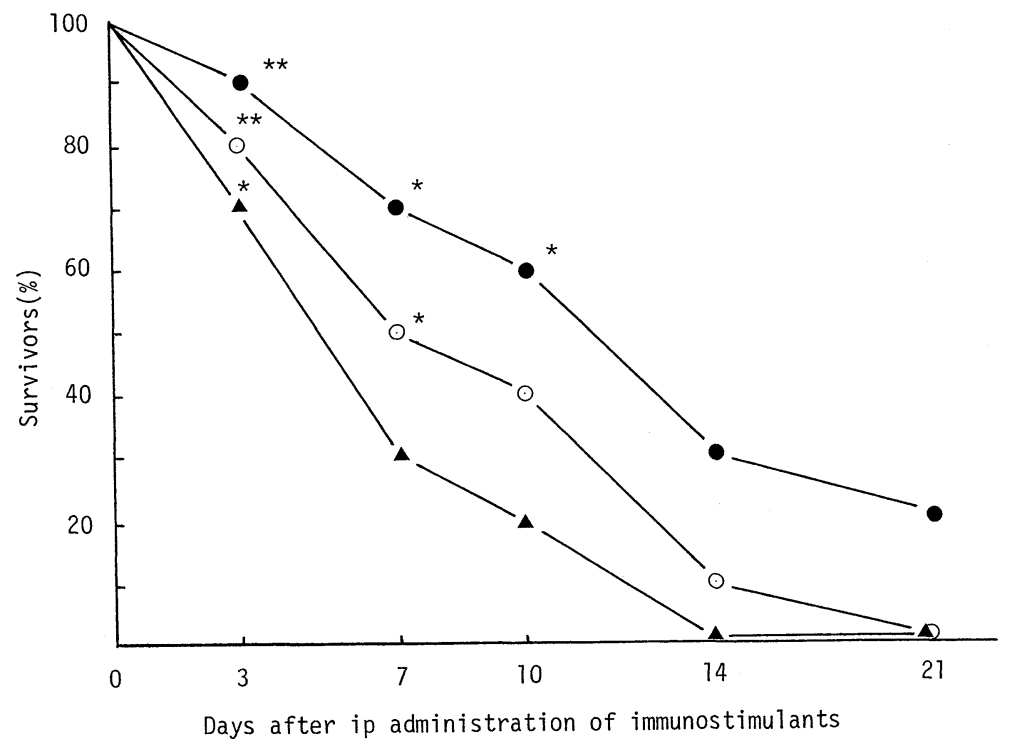

Mice ( $\mathrm{n}=10)$ were challenged ip with $P$. aeruginosa $\left(1.8 \times 10^{7} \mathrm{CFUs}\right) 3,7,10,14$ or 21 days after ip inoculation with or without $0.5 \mathrm{mg}$ of AS 15557 (O), AA $29522(\bigcirc)$ or LC $9018(\boldsymbol{A})$. The survival rates were recorded on day 10 after the challenge. ${ }^{*} P<0.05,{ }^{* *} P<0.01$. 
Fig. 1 shows the changes in survival rates of mice (\%) infected ip with $P$. aeruginosa at indicated intervals after ip administration of AS 15557, AA 29522 or LC 9018 (0.05 mg/mouse: $2 \mathrm{mg} / \mathrm{kg})$. All control grouup mice died within $24 \mathrm{hr}$ after the infection, while $60 \%$ of mice survived if they were challenged on the 10th day after the ip administration of AS $15557(P<0.05)$. On the other hand, significant numbers of survivor mice were noted on the 7th day with AA 29522 and on the 3rd day with LC 9018.

Effective actions against $P$. aeruginosa infection in normal mice based on routes of immunostimulant administration

Mice $(n=10)$ were infected ip, iv or sc with $P$. aeruginosa on the 3 rd day after the ip, iv or sc administration of AS 15557 or LC 9018 (Table 2). In the case of the same routes of inoculation and infection (ip via ip, iv via iv and sc via sc), host resistance-enhancing capacities were seen in the AS 15557-administered and the LC 9018-administered groups. Howerver, with differing routes such as ip via iv, ip via sc and iv via sc, there was no significant protective effect against $P$. aeruginosa infection.

Table 3 Minimal effective dose of immunostimulants against $P$. aeruginosa infection in normal mice

\begin{tabular}{|c|c|c|c|c|c|c|c|}
\hline \multirow{3}{*}{ Groups } & \multicolumn{7}{|c|}{ Survivors (\%) } \\
\hline & \multicolumn{7}{|c|}{ Dose of inoculum ; mg/mouse $(\mathrm{mg} / \mathrm{kg})$} \\
\hline & $\begin{array}{c}0 \\
(0) \\
\end{array}$ & $\begin{array}{c}0.01 \\
(0.4) \\
\end{array}$ & $\begin{array}{c}0.05 \\
(2.0)\end{array}$ & $\begin{array}{c}0.1 \\
(4.0)\end{array}$ & $\begin{array}{c}0.2 \\
(8.0) \\
\end{array}$ & $\begin{array}{c}0.5 \\
(20) \\
\end{array}$ & $\begin{array}{l}1.0 \\
(40)\end{array}$ \\
\hline AS 15557-administered & 0 & 40 & $60^{*}$ & $60^{*}$ & $70^{*}$ & $90^{* *}$ & $100^{* *}$ \\
\hline LC 9018-administered & 0 & 10 & 20 & 40 & $60^{*}$ & $80^{* *}$ & $70^{*}$ \\
\hline
\end{tabular}

Table 4 Comparison of protective actions of immunostimulants against $P$. aeruginosa infection in immunosuppressed mice

\begin{tabular}{cccc}
\hline \multirow{2}{*}{ Groups } & \multicolumn{3}{c}{ Survivors $(\%)$} \\
\cline { 2 - 4 } & \multicolumn{3}{c}{$\mathrm{mg} / \mathrm{mouse}(\mathrm{mg} / \mathrm{kg})$} \\
\cline { 2 - 4 } & 0 & 0.1 & 0.5 \\
& $(0)$ & $(4.0)$ & $(20)$ \\
\hline Untreated normal & 20 & - & - \\
DM-treated alone & 0 & - & - \\
+ AS 15557 & & $60^{*}$ & $80^{* *}$ \\
+ AA 29522 & & 30 & $60^{*}$ \\
+ LC 9018 & & 20 & $60^{*}$ \\
+ OK-432 & & 10 & 40 \\
\hline
\end{tabular}

One day after the last ip treatment with dexamethasone (DM ; total inoculum : $0.6 \mathrm{mg} /$ mouse), mice $(\mathrm{n}=10)$ were injected ip with one of two concentrations $(0.1$ and 0.5 mg) of AS 15557, AA 29522, LC 9018 or OK-432. Three days after injection of these immunostimulants, mice were challenged ip with $P$. aeruginosa $\left(6.2 \times 10^{7} \mathrm{CFUs}\right)$ and the survival rates were recorded on day 10 after the challenge.

${ }^{*} p<0.05,{ }^{* *} p<0.01$. 
Minimal effective immunostimulant dose against $P$. aeruginosad inection in normal mice

Mice $(n=10)$ were inoculated ip with or without various doses of AS 15557 or LC 9018, and then infected ip with $P$. aeruginosa 3 days after the inoculation. As shown in Table 3 , the minimal effective doses of AS 15557 and LC 9018 were $0.05 \mathrm{mg} / \mathrm{mouse}(2 \mathrm{mg} / \mathrm{kg})$ and $0.2 \mathrm{mg} / \mathrm{mouse}(8 \mathrm{mg} / \mathrm{kg})$, respectively, that is, the minimal effective dose of AS 15557 was a quarter that of LC 9018 .

Comparison of protective actions of immunostimulants against $P$. aeruginosa infection in mice immunosuppressed with dexamethasone (DM)

As shown in Table 4, $20 \%$ of normal control mice survived when they were challenged ip with P. aeruginosa $\left(6.2 \times 10^{6} \mathrm{CFUs}\right)$, while there were no survivors in the DM-treated group. In contrast, improved survival rates of DM-treated mice which had been inoculated ip with one of the four kinds of immunostimulants $(0.5 \mathrm{mg})$ were observed in all experimental groups, and the host resistanceenhancing capacities of these immunostimulants were dose-dependent. When DM-treated mice were inoculated with $0.1 \mathrm{mg}$ of these immunostimulants, a significant survival rate (60\%) was seen only in the AS 15557-administered group.

In vivo killing activity against $P$. aeruginosa infection of PECs from immunosuppressed mice injected ip with immunoestimulants.

As shown in Fig. 2, the in vivo killing activity against $P$. aeruginosa $\left(1.0 \times 10^{5} \mathrm{CFUs} / \mathrm{mouse}\right)$ of PECs $(-28 \pm 9 \%)$ from DM-treated mice was lower than that of PECs $(-9 \pm 3 \%)$ from untreated normal mice. The reduced killing activity of PECs from DM-treated mice was markedly restored when these mice were injected ip with either AS 15557, LC 9018 or OK-432 3 days before the ip challenge. However, the PEC-enhancing capacity of AS 15557 was significantly greater than that of LC 9018 or OK-432 $(P<0.05)$, that is, the mean killing activities of PECs induced by AS 15557, LC 9018 and OK- 432 were 82,65 and 51\%, respectively. In addition, there were no remarkable differences in the number of PECs or the PEC cell population elicited by AS $15557\left(2.8 \times 10^{7}\right.$ cells/mouse, macrophage $=\mathrm{M} \phi \mathrm{s} ; 66.2 \%$, polymorphonuclear cells $=$ PMNs: $9.6 \%)$, LC $9018\left(3.2 \times 10^{7}\right.$ cells $/$ mouse,

Fig. 2 In vivo killing activity against $P$. aeruginosa infection of PECs from immunosuppressed mice injected ip with immunostimulants

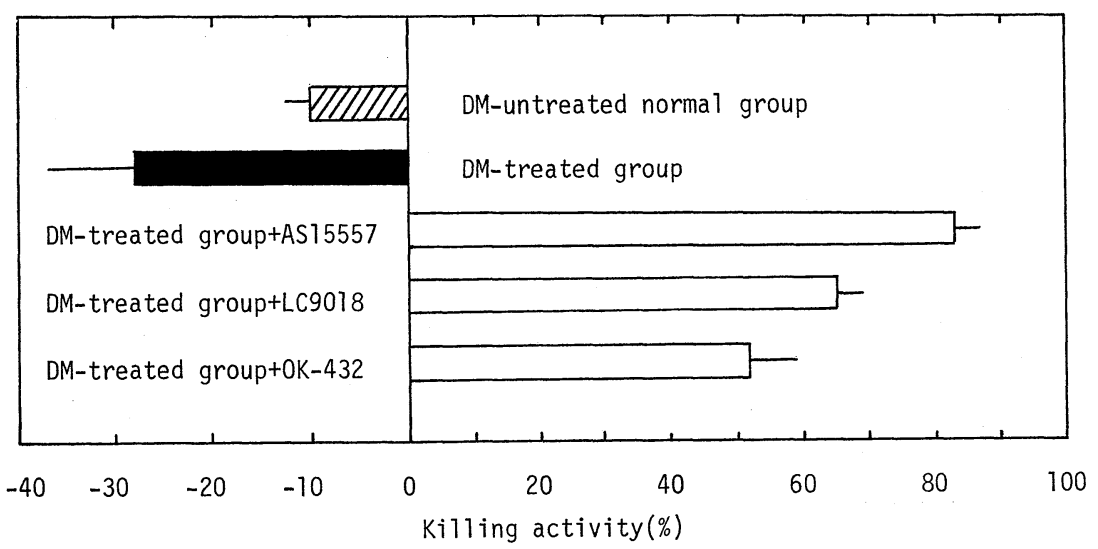

Mice $(\mathrm{n}=3)$ immunosuppressed with dexamethasone $(\mathrm{DM})$ were challenged ip with $P$. aeruginosa $\left(1.0 \times 10^{5}\right.$ CFUs) 3 days after ip inoculation with $(\square)$ or without $(\boldsymbol{\square}) 0.1 \mathrm{mg}$ of each immunostimulant. Untreated normal mice $(\mathrm{n}=3)$ were also challenged with $P$. aeruginosa (wa). Killing activities of PECs from these mice $3 \mathrm{hr}$ after infection were determined as described in "Materials and Methods". 
Table 5 Histopathological liver and spleen findings of mice given ip immunostimulants

\begin{tabular}{|c|c|c|c|c|c|}
\hline \multirow{2}{*}{ Organs } & \multirow{2}{*}{ Item } & \multirow{2}{*}{$\begin{array}{l}\text { None } \\
\text { (Control) }\end{array}$} & \multicolumn{3}{|c|}{ Immunostimulant administered } \\
\hline & & & AS 15557 & LC 9018 & OK-432 \\
\hline \multicolumn{6}{|l|}{ [Liver] } \\
\hline & $\begin{array}{l}\text { bacterial clumping } \\
\text { in histiocytes }\end{array}$ & $(-)$ & $(-)$ & $(+)$ & $( \pm)$ \\
\hline & $\begin{array}{l}\text { monocytes, PMN } \\
\text { infiltration of } \\
\text { sinusoids }\end{array}$ & $(-)$ & $( \pm)$ & $(+)$ & $( \pm)$ \\
\hline & $\begin{array}{l}\text { necrosis of } \\
\text { hepatic cells }\end{array}$ & $(-)$ & $( \pm)$ & $(+)$ & $( \pm)$ \\
\hline & $\begin{array}{l}\text { reconstruction of } \\
\text { liver acinus }\end{array}$ & $(-)$ & $(-)$ & $( \pm)$ & $(-)$ \\
\hline \multicolumn{6}{|l|}{ [Spleen] } \\
\hline & $\begin{array}{l}\text { red pulp } \\
\text { (giant cells) }\end{array}$ & $( \pm)$ & $(+)$ & $(H)$ & $(+)$ \\
\hline & white pulp & normal & normal & normal & normal \\
\hline \multicolumn{6}{|c|}{$\begin{array}{l}(-) \text {; negative, }( \pm) \text {; false positive, }(+) \text {; positive, }(+) \text {; strongly positive. Mice } \\
(\mathrm{n}=3) \text { were injected ip with either } 0.5 \mathrm{mg}(20 \mathrm{mg} / \mathrm{kg}) \text { of AS } 15557 \text {, LC } 9018 \text { or OK- } \\
432 \text {. Livers and spleens were removed on the } 10 \text { th day after inoculation, and fixed } \\
\text { in } 10 \% \text { formalin. As controls, mice }(\mathrm{n}=3) \text { were injected ip with saline }(0.2 \mathrm{ml}) \text {. } \\
\text { Tissue sections of each organ were made from all fixed preparations and stained } \\
\text { with hematoxylin and eosin solution. }\end{array}$} \\
\hline
\end{tabular}

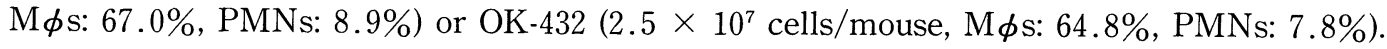
Histopathological features of liver and spleen from mice injected ip with immunostimulants

Histopathological findings of the liver and spleen from mice $(n=3) 10$ days after ip administration of AS 15557, LC 9018 or OK-432 (0.5 mg/mous) are summarized in Table 5 . In the livers of mice inoculated with LC 9081, a large number of small and intermediate nodular infiltrations consisting of inflammatory cells, mainly monocytes together with neutrophils, were prominent in sinusoids with an irregular distruibution to lobules. The major lesions were composed of necrosis of hepatic cells, that is, severe necrotizing inflammatory lesions of the septic type. Histopathological changes in the livers of mice inoculated ip with AS 15557 or OK-432 were relatively mild as compared to those observed with LC 9018. On the other hand, the appearance of giant cells in the red pulp of the spleen was evoked by the administration of all of the immunostimulants tested, though the degree was more severe with LC 9018 and OK-432 than with AS 15557. In contrast, none of the experimental cases showed histopathological changes in the white pulp.

$\mathrm{LD}_{50}$ values of immunostimulants in normal mice

In the case of ip administration, $\mathrm{LD}_{50}$ values of AS 15557, LC 9018 and OK-432 in normal female mice were 812,561 and $141 \mathrm{mg} / \mathrm{kg}$, respectively. $\mathrm{LD}_{50}$ values of AS 15557, LC 9018 and OK-432 utilizing iv administration were 200,177 and $31 \mathrm{mg} / \mathrm{kg}$, respectively. The $\mathrm{LD}_{50}$ value of AS 15557 with oral administration was $3000 \mathrm{mg} / \mathrm{kg}$ or more. Thus, the toxicity of AS 15557 was markedly lower than that of LC 9018 or OK-432 (data not shown).

\section{Discussion}

This study was concluded to determine whether or not a single ip inoculation of heat-killed AS 15557, which is known to be present as a commensal agent in several animals ${ }^{17 \sim 20)}$, would lead to enhanced host defense mechanisms against opportunistic infections involving $P$. aeruginosa, MRSA and C. albicans. 
Despite there being no differences from normal mice in the numbers of PECs and peritoneal $\mathrm{M} \phi \mathrm{s}$ ip with AS 15557, LC 9018 or OK-432, the duration of enhanced resistance to P. aeruginosa infection in AS 15557-administered normal mice was statistically superior to that in LC 9018-administered or OK-432-administered normal mice. The minimal effective dose of AS 15557 was also lower than that of LC 9018.

The in vivo killing activity of $\mathrm{M} \phi$ s-rich PECs against $P$. aeruginosa 3 days after ip administration of AS 15557 was stronger than that of PECs from mice pretreated ip with LC 9018 or OK-432. Thus, the host resistance-enhancing capacity of AS 15557 was comparatively higher than those of the other bacterial immunostimulants tested. The strong protective effect of AS 15557 can not be convincingly explained by the results obtained. A possible explanation may be the presence of heat-stable specific constituents in the cell wall and/or in the cell membrane of AS 15557, and if so, these constitutents would play an improtant role in the efficient enhancement of resistance to bacterial infections. In hight of this speculation, studies on extraction, purification and the biological actions of various cellular fractions of AS 15557 cells will undertaken.

Previous investigators have reported that cellular immunity is not important for protection against $P$. aeruginosa infection, because the main effector cells are PMNs, and their functions are enhanced in the presence of specific immunoglobulins ${ }^{22,23)}$. On the contrary, some authors attribute the protective mechanism against $P$. aeruginosa infection to cellular immunity, proposing in particular that $\mathrm{M} \phi$ s play a critical role in the control of this infection ${ }^{24 \sim 26)}$. In our preliminary studies, it was found that a high percentage of PMNs was observed in the mouse peritoneal cavity at 3 to $24 \mathrm{hr}$ after ip admininstrtion of AS 15557 (52 $\pm 2 \%$ ) and drastically decreased thereafter, whereas the mean percentage of $\mathrm{M} \phi \mathrm{s}$ began to increase 2 days after the injection of AS 15557 (69\%), peaked on the 5 th to 7 th day (86\%) and was maintained at a high level even on the 14 th day (75\%). These observations may suggest that the early stage of protection against $P$. aeruginosa infection in AS 15557administered mice is due to inflammatory PMNs rapidly accumulating in the infected sites, while the enhanced resistance in the late stage may be attributable to $M \phi$ s mediated by AS 15557 . Our speculation appears to be supported by the findings that host resistance to $P$. aeruginos a infection in granulocytopenic animals is enhanced by the administration of BCG in complete Freund's adjuvant ${ }^{25}$. The acquisition of enhanced resistance to $P$. aeruginosa infection was also explained by the difference in the accumulation and/or activation of PECs (mainly $\mathrm{M} \phi \mathrm{s}$ ) at the site of infection.

Corticosteroids strongly suppress cell-mediated immunity, and consequently the susceptibility of drug-treated patients or animals to opportunistic infections may be relatively higher than that of normal subjects ${ }^{2729}$. In the present study, survival rates of DM-treated mice infected ip with $P$. aeruginosa were lower than those of untreated normal mice, though the survival rates of DM-treated mice were elevated by the administration of AS 15557. The suppressed in vivo killing activity against $P$. aeruginosa of PECs from DM-treated mice was markedly enhanced by the administration of AS 15557, because corticosteroids dramatically suppress various biological properties of $\mathrm{M} \phi \mathrm{s}$ but do not affect PMN functions ${ }^{11,27}$. These speculations are strongly supported by the report of Stinnett et $a l{ }^{30)}$, which showed that the protective effect of $C$. parvum vaccine on mice receiving high doses of cortisone acetate was attributable to the activation of $\mathrm{M} \phi \mathrm{s}$ induced by this immunostimulant.

The histopathological changes observed in the livers and spleens of AS 15557-administered mice were very mild as compared with those in LC 9018-administered mice. The differences in histopathological changes between AS 15557 and LC 9018 may be due to the morphological differences between these bacteria ${ }^{16,17)}$.

Based on the results presented herein, it is reasonable to propose that the AS 15557 preparation be added to the armamentarium of bacterial immunostimulants. 


\section{References}

1) Senterfitt VC \& Shads JW Jr.: Salmonellosis in mice infected with Mycobacterium bovis BCG. II. resistance to infection. Infect Immun 1970; 1: 583-586.

2) Zbar B, Bernstein ID, Bartlett L \& Rapp HJ Jr.: Immunotherapy of cancer: regression of intradermal tumors and prevention of growth of lymph node metastasis after intralesional injection of living Mycobacterium bovis. J Natl Cancer Inst 1972; 49: 119-130.

3) Israel L, Bdelstein R, Depierre A \& Dimitrov N.: Daily intravenous infusions of Corynebacterium parvum in twenty patients with disseminated cancer. J Natl Cancer Inst 1975; 53: 29-33.

4) Tamecki J.: Immunoregulation of antitumor response: Differential secretion of arachidonic acid metabolities by macrophages during stimulation in vitro with BCG and Corynebacterium parvum. Arch immunol Ther Exp 1993; 41: $45-50$.

5) Sher NA, Chapars SD, Greenberg LE \& Bernard S.: Effects of BCG, Corynebacterium parvum and methanolextraction residue in the reduction of mortality from Staphylococcus aureus and Candida albicans infections in immunosuppressed mice. Infect Immun 1975; 12: 1325-1330.

6) Chen L, McGowan P \& Ashe S.: B7-1/CD80-transduced tumor cells elicit better systemic immunity than wild-type tumor cells admixed with Corynebacterium parvum. Cancer Res 1994; 54: 5420-5423.

7) Kimura I, Ohonoshi T \& Machida K.: Immunotherapy in human lung cancer using streptococcal agent, OK-432. Cancer 1978; 37: 2201-2203.

8) Mizoguchi Y, Tsutsui H \& Yamatoto S.: Studies on hepatoma cells injury by antibody-dependent cell-mediated cytotoxicity and its augmentation by pretreatment of macrophages with OK-432. Allergy 1984; 33: $135-141$.

9) Watanabe $T$ \& Yamori T.: Suppressive effects of the bacterial immunostimulant OK-432 on the incidence of spontaneous thymic lymphoma in AKR mice. Int J Med Microbiol 1989; 271: 330-338.

10) Okamoto H, Shoin S \& Shimizu R.: Studies on the anticancer and streptolysin S-forming abilities of hemolytic streptococci. Microbiol Immunol 1967; 11: 323-336.

11) Watanabe $T \&$ Saito H.: Protection of mice against herpes simplex virus infection by Lactobacillus casei preparation (LC 9018) in combination with inactivated viral antigen. Microbiol Immunol 1986; 30: 111-122.

12) Watanabe T \& Saito H.: Effects of PSK ointment, OK-432 ointment and LC 9018 ointment of PSeudomonas burn wound infection in mice. J Dermatol 1987; 14: 346-351.

13) Watanabe T \& Yatani R.: Protective effect of Lactobacillus casei on methicillin-resistant Staphylococcus aureus infection in mice. Mie Med J 1993; 43: 237-242.

14) Yasutake N, Ohwaki M \& Mutai M.: Antitumor effect of humoral and cellular immunities mediated by a bacterial immunopotentiator, Lactobacillus casei, in mice. Cancer Immunol Immunother 1985; 20: 109-116.

15) Kato I, Yokokura T \& Mutai M.: Effects of oral administration of Lactobacillus casei on antitumor responses induced by tumor resection in mice. Int J Immunopharmacol 1994; 16: 29-36.

16) Sato K.: Enhancement of host resistance against listerial infection by Lactobacillus casei: role of macrophages. Infect immun 1984; 44: 445-451.

17) Phillips JE.: Actinobacillus In Bergey's Manual of Systematic Bacteriology. (Krieg, E. and Holt, J.G ed) Williams and Wilkins Co. 1984; 1: 570-575.

18) Burrows LL \& Lo RYC.: Molecular characterization of RIX toxin determinant from Actinobacillus suis. Infect Immun 1992; 60: 2166-2173.

19) Jang SS, Biberstein EL \& Hirsh DC.: Actinobacillus suis-like organisms in horses. Am J Vet Res 1987; 48: $1036-1038$

20) Mair NSC, Randall CJ, Thomas GW \& Cowl KP.: Actinobacillus suis infections in pigs. J Comp Pathol 1974; 84: $113-119$.

21) Reed LJ \& Muench H.: A simple method of estimating fifty percent endopoints. Am J Hyg 1983; 27: 493-497.

22) Finch JE \& Brown MRW.: Effect of growth environment on Pseudomonas aeruginosa killing by rabbit polymorphonuclear leukocytes and cationic proteins. Infect Immun 1978; 20: 340-346.

23) Tatsukawa K, Takeya K \& Nomoto K.: Differing contribution of polymorphonuclear cells and macrophages to protection of mice against Listeria monocytogenes and Pseudomonas aeruginosa. J Gen Microbiol 1979; 115: $161-166$.

24) Bartell PF \& Krikszens A.: Influence of antislime glycolipoprotein serum on interaction between Pseudomonas aeruginosa and macrophages. Infect Immun 1980; 27: 777-783.

25) Buhles WC JR \& Shifreine M.: Adjuvant protection against bacterial infection in granulocytopenic mice. J Infect Dis 1977; 136: $90-95$. 
26) Pennington JE \& Kuchmy D.: Mechanism for pulmonary protection by lipopolysaccharide Pseudomonas vaccine. J Infect Dis 1980; 142: 191-198.

27) Balow JE \& Rosenthal AS.: Glucocorticoid suppression of macrophage migration inhibitory factor. J Exp Med 1983; 137: 1031-1041.

28) Rinehart JJ, Balcerzak SP \& LoBuglio AF.: Effects of corticosteroids on human monocyte function. J Clin Invest 1984; 54: 1337-1343.

29) Webel ML, Ritts RE JR \& Woods JE.: Cellular immunity after intravenous administration of methyl predonisolone. J Lab Clin Med 1984; 83: 383-392.

30) Stinnett JD, Morris MJ \& Alexander JW: Macrophage activation and increased resistance to infection in immunosuppressed mice treated with Corynebacterium parvum or pyran copolymer. J Reticuloendothel Soc 1979; 25: $525-531$.

\title{
Actinobacillus suis の正常および免疫不全マウスにおける 細菌感染抵抗性増強効果
}

\author{
鈴鹿医療科学技術大学, 保健衛生学部, 医療栄養学科
}

渡邊隆 司

\section{要旨}

加熱処理 $A$. suis ATCC 15557 (AS 15557) の $0.5 \mathrm{mg}(4 \mathrm{mg} / \mathrm{kg})$ を正常およびデキサメゾン処 置マウス腹腔内 (ip) に投与したのち, 患者由来緑 膿菌，メチシリン耐性黄色ブドウ球菌（MRSA） あるいは Candida albicans をマウス ip 内に感染 させたところ，非投与対照群におけるよりも高い 生存率を示すと共に, 免疫増強能を有することが 知られている加熱処理 Lactobacillus casei YIT 9018 (LC 9018) およびペニシリン処理 Streptococcus pyogenes $\mathrm{Su}(\mathrm{OK}-432)$ よりも高い值を示し
た. AS 15557の緑膿菌感染抵抗性持続効果並びに 最小有効量は LC 9018およびOK-432のそれらよ りも優れていた.デキサメゾン処理によって低下 した腹腔浸出細胞（特にマクロファージ）の生体 内緑膿菌殺菌能はAS 15557を投与することによ り著しく回復した.AS 15557による毒性および病 理組織学的変化はLC 9018および OK-432におけ るよりも極めて軽度であった，以上の結果より， AS 15557は日和見菌感染に対して優れた宿主抵 抗増強作用を有する細菌性免疫増強剤であること が示唆された。 